\title{
The distribution of ascorbic acid between various cellular components of blood, in normal individuals, and its relation to the plasma concentration
}

\author{
BY RICHARD M. EVANS ${ }^{*}$, LILIAS CURRIE ${ }^{1}$ AND ALLAN CAMPBELL \\ ${ }^{1}$ Department of Clinical Biochemistry and ${ }^{2}$ Department of Medicine, Hairmyres Hospital, \\ East Kilbride, Lanarkshire, G75 8RG
}

(Received 16 February 1981 - Accepted 5 January 1982)

1. A study was undertaken to investigate the distribution of ascorbic acid between various cellular components of blood, in normal individuals, and its relation to the plasma concentration. Forty-one unsupplemented individuals and sixteen supplemented $(2 \mathrm{~g} / \mathrm{d}$ for $5 \mathrm{~d})$ individuals were studied.

2. Granulocytes, mononuclear leucocytes, platelets and erythrocytes were separated by differential sedimentation and centrifugation. Ascorbic acid contents were measured by the dinitrophenylhydrazine method.

3. Ascorbic acid content per cell was higher in mononuclear leucocytes and granulocytes than in platelets and erythrocytes. Intracellular ascorbic acid concentrations, calculated from published values for cell volumes, when compared with the plasma concentration showed a marked ability to concentrate ascorbic acid in mononuclear leucocytes ( 80 times), platelets ( 40 times) and granulocytes ( 25 times).

4. Erythrocytes showed little ability to concentrate ascorbic acid over the normal range of plasma concentration but because of their relative numbers they and the plasma fraction accounted for most of the blood-borne ascorbic acid $(>70 \%)$.

5. The ascorbic acid content of granulocytes, platelets and erythrocytes showed a significant positive correlation with the plasma concentration and supplementation with ascorbic acid significantly increased the content of these cell types. Mononuclear leucocytes in contrast did not show any such relationship.

6. The ability of the mononuclear leucocytes to maintain the highest levels of ascorbic acid in the cell types studied, despite variation in plasma availability, warrants further study, particularly in view of the importance of these cells in immunocompetence.

The ascorbic acid content of the plasma and the leucocytes (buffy layer) has been studied extensively both in health and in disease (Denson \& Bowers, 1961; Hume \& Weyers, 1973; Barton \& Roath, 1976; Vallance et al. 1978) and a relationship has been demonstrated between the leucocyte ascorbic acid (buffy layer) and the plasma ascorbic acid (Griffiths et al. 1967; Loh \& Wilson, 1971a). However, few studies have attempted to define the distribution of ascorbic acid in the various cellular constituents of the blood (Barkhan \& Howard, 1958; Vallance et al. 1978) and its relationship with the plasma levels. We believe that this is of importance, particularly since we have suggested that conclusions based on the standard leucocyte (buffy layer) ascorbate may be incorrect due to variation in the relative contribution of platelet ascorbic acid to the leucocyte (buffy layer) ascorbic acid content (Evans et al. 1980).

In this report, we define relationships, in normal individuals, between the plasma ascorbic acid and the ascorbic acid content of granulocytes, mononuclear cells (mainly lymphocytes), platelets and erythrocytes, and discuss the possible significance of our findings.

\section{SUBJECTS AND METHODS}

\section{Subjects}

Forty-one individuals (twenty-one females, twenty males) aged 17-55 (mean 27 years) volunteered for this study. They were all non-smokers, apparently healthy, and not taking any vitamin supplements. Sixteen of them were later supplemented with ascorbic acid $(2 \mathrm{~g} / \mathrm{d}$ orally for $5 \mathrm{~d}$ ). 


\section{Specimens}

A venous blood specimen (10 ml EDTA) was obtained from each subject. Analysis was begun within $0.5 \mathrm{~h}$ of venesection. Full blood counts were made using standard haematology techniques.

\section{Separation procedures}

These were based on the differential sedimentation and centrifugation techniques described by Barkhan \& Howard (1958) and Boyum (1968).

To minimize cell damage plastic equipment was used and cell pellets were resuspended, with minimum delay, by gently drawing the cells in and out of a pasteur pipette.

Ficoll-sodium diatizoate (Ficoll-Paque; Pharmacia Fine Chemicals; $2 \mathrm{ml}$ ) was placed in two tubes and each carefully overlayered with blood $(3 \mathrm{ml})$. The specimen was split to speed up the sedimentation. When the erythrocytes settled to the bottom of the tubes the upper layers containing plasma, leucocytes and platelets were removed, pooled and adjusted to $3.5 \mathrm{ml}$ with saline $(9 \mathrm{~g}$ sodium chloride/l). A portion $(3 \mathrm{ml})$ was taken for further fractionation and saline $(2 \mathrm{ml})$ added to the remainder which constituted the buffy layer preparation.

The portion of cells from the previous stage was overlayered on Ficol-Paque $(2 \mathrm{ml})$ and centrifuged at $350 \mathrm{~g}$ for $20 \mathrm{~min}$. The upper layer and the cells at the interface were removed together with the top $0.5 \mathrm{ml}$ of the lower layer. The rest of the lower layer was carefully removed and discarded. The pellet was resuspended in $2.5 \mathrm{ml}$ saline and constituted the granulocyte preparation.

The upper layer from the previous step was centrifuged at $350 \mathrm{~g}$ for $20 \mathrm{~min}$. The supernatant fraction was removed for further fractionation. The pellet was resuspended in $3 \mathrm{ml}$ saline and centrifuged at $50 \mathrm{~g}$ for $10 \mathrm{~min}$. The supernatant fraction was removed, discarded and the pellet resuspended in $2.5 \mathrm{ml}$ saline. This constituted the mononuclear cell preparation.

The supernatant fraction from the previous stage was centrifuged at $50 \mathrm{~g}$ for $10 \mathrm{~min}$. The supernatant fraction was removed and if required adjusted to $2.5 \mathrm{ml}$ with saline. This constituted the platelet preparation.

Blood $(2 \mathrm{ml}$ ) was centrifuged at $1400 \mathrm{~g}$ for $10 \mathrm{~min}$. The plasma was removed and kept for the estimation of plasma ascorbic acid. The buffy layer was removed and discarded. The erythrocytes were washed twice by resuspending in saline $(3 \mathrm{ml})$, centrifuging as before and removing the supernatant. Finally, the erythrocytes were resuspended in $2.5 \mathrm{ml}$ saline. This constituted the erythrocyte preparation.

A portion $(2 \mathrm{ml})$ of each cell preparation was taken for ascorbic acid extraction and the remainder was used to obtain cell counts.

\section{Extraction of ascorbic acid}

Plasma ascorbic acid was extracted by adding $0.5 \mathrm{ml} 0.6 \mathrm{M}$-trichloroacetic acid (TCA) to $0.2 \mathrm{ml}$ plasma, mixing and centrifuging at $1400 \mathrm{~g}$ for $10 \mathrm{~min}$. A portion $(0.2 \mathrm{ml})$ was taken for ascorbic acid analysis.

Ascorbic acid was extracted from the buffy layer, granulocyte, mononuclear cell, and erythrocyte preparations after centrifugation at $1400 \mathrm{~g}$ for $20 \mathrm{~min}$. The supernatant was completely removed and $0.25 \mathrm{ml} 0.6 \mathrm{M}$-TCA $(0.5 \mathrm{ml}$ for the erythrocyte preparation because there were more cells) added to the pellet. The cells were homogenized using a glass rod, allowed to stand for at least $10 \mathrm{~min}$ and centrifuged at $1400 \mathrm{~g}$ for $10 \mathrm{~min}$. A portion $(0.2 \mathrm{ml})$ was removed and used for ascorbic acid analysis.

The procedure for the platelet preparation was modified to allow for incomplete pelleting of the platelets and contamination of the pellet with residual plasma ascorbic acid. After 
Table 1. Recovery of different cell types in the various cell preparations from ten healthy individuals

\begin{tabular}{llcccc}
\hline \hline Lean initial cell & Leucocytes & Granulocytes & Mononuclears & Platelets & Erythrocytes \\
numbers $\left(\times 10^{-9}\right)$ & $\ldots$ & 0.020 & 0.018 & 1.37 & 4.94 \\
\hline
\end{tabular}

Fraction

Mean (range) \% initial cell recovery

\begin{tabular}{lccccc}
\cline { 2 - 6 } Buffy layer & $46(35-59)$ & $49(37-65)$ & $39(18-53)$ & $70(58-83)$ & $0 \cdot 2(0 \cdot 1-0 \cdot 5)$ \\
Granulocyte & - & $30(21-36)$ & $0.8(0-1 \cdot 5)$ & $0.6(0.4-1)$ & $0.15(0 \cdot 1-0 \cdot 2)$ \\
Mononuclear & - & $0.3(0-1 \cdot 0)$ & $22(10-27)$ & $3.2(2-4)$ & $<0.1$ \\
Platelet & - & - & $1.2(0-4)$ & $21(16-27)$ & $<0.1$ \\
Erythrocyte & $0.6(0 \cdot 1-2 \cdot 1)$ & - & - & $<0.3$ & $21(16-25)$ \\
\hline
\end{tabular}

Only a portion ( $(\xi)$ of the buffy layer fraction was used for ascorbic acid determination. The rest was used for the separation of the other cell fractions.

centrifugation at $1400 \mathrm{~g}$ for $20 \mathrm{~min}$, the supernatant was removed and kept for platelet counting so that the number of platelets in the pellet could be calculated from the difference between the count before and after centrifugation. The pellet was washed with saline $(2 \mathrm{ml})$, centrifuged and the ascorbic acid extracted with TCA as for the other preparation.

\section{Cell counting}

Leucocyte and erythrocyte numbers in the various cell fractions were measured on a portion (usually $0.2 \mathrm{ml}$ ) diluted with $10 \mathrm{ml}$ of balanced electrolyte solution (Isoton II, Coulter Electronics Ltd) using an automated cell counter (Coulter model S, Coulter Electronics Ltd).

Platelet numbers in the various cell fractions were measured on a dilution ( 1 in 400 or 1 in 3000 ) with Isoton $(20 \mathrm{ml})$ using an automated platelet counter (Coulter model C, Coulter Electronics Ltd).

Microscopic examination of the various cell fractions was carried out using standard haematology techniques.

\section{Analysis of ascorbic acid}

The assay is a micro modification of the dinitrophenylhydrazine method of Denson $\&$ Bowers (1961). Portions $(0.2 \mathrm{ml})$ of standard $(5 \mathrm{mg} / \mathrm{l})$, blank and extracts were taken and $0.05 \mathrm{ml}$ dinitrophenylhydrazine reagent added. After incubation overnight at room temperature they were frozen and $0.25 \mathrm{ml}$ concentrated sulphuric acid added; this ensured that excessive heating did not occur. The absorbance at $520 \mathrm{~nm}$ against a water blank was measured using a microcell (pathlength $10 \mathrm{~mm}$ ). Under these conditions the assay had a sensitivity of $0.03 \mu \mathrm{g}$ ascorbic acid per portion and was linear up to $3 \mu \mathrm{g}$. Cellular content of ascorbic acid is expressed as $\mu \mathrm{mol} / 10^{\circ}$ cells and plasma concentration as $\mu \mathrm{mol} / 1$.

\section{RESULTS}

\section{Recovery of different cell types in the various cell preparations}

The recovery of different cell types in the various cell preparations from ten healthy individuals was determined. The results (Table 1) showed that each of the cell preparations had some degree of contamination with other cell types. However, the separation of granulocytes and mononuclear cells was adequate and the erythrocyte contamination of each preparation was minimal. The major contaminants were platelets in the mononuclear cell preparation. In order to correct for this contamination the platelet count in the mononuclear cell preparation was routinely measured. 
Table 2. Ascorbic acid content (umol/109 cells) of various blood fractions from forty-one healthy individuals (twenty-one females, twenty males) and from sixteen of them (eleven females, five males) after supplementation with ascorbic acid

\begin{tabular}{|c|c|c|c|c|c|c|c|c|}
\hline \multirow[b]{2}{*}{ Fraction } & \multicolumn{2}{|c|}{ Male } & \multicolumn{2}{|c|}{ Female } & \multicolumn{2}{|c|}{ Over-all } & \multicolumn{2}{|c|}{ Supplemented } \\
\hline & Mean & SD & Mean & SD & Mean & SD & Mean & SD \\
\hline Buffy layer & $1 \cdot 78$ & 0.56 & $2 \cdot 02$ & 0.51 & 1.91 & $0 \cdot 54$ & $2 \cdot 51^{*}$ & 0.78 \\
\hline Granulocyte & 0.53 & $0 \cdot 17$ & 0.54 & $0 \cdot 12$ & 0.53 & $0 \cdot 14$ & $0.71^{* *}$ & 0.14 \\
\hline Mononuclear & $1 \cdot 71$ & 0.45 & $1 \cdot 68$ & 0.47 & $1 \cdot 70$ & 0.45 & $1 \cdot 74$ & 0.58 \\
\hline (Platelet corrected) & $1 \cdot 39$ & 0.33 & $1 \cdot 36$ & $0 \cdot 37$ & $1 \cdot 37$ & $0 \cdot 35$ & $1 \cdot 39$ & 0.43 \\
\hline Platelet & $0 \cdot 031$ & 0.016 & 0.030 & $0 \cdot 010$ & 0.030 & 0.013 & $0.055^{* * *}$ & $0 \cdot 019$ \\
\hline Erythrocyte & 0.0033 & 0.0012 & 0.0044 & 0.0013 & 0.0039 & 0.0014 & $0.0059 * *$ & 0.0016 \\
\hline Plasma $(\mu \mathrm{mol} / 1)$ & 37 & 19 & 53 & 21 & 45 & 22 & $118^{* * *}$ & 36 \\
\hline
\end{tabular}

Pre- and post-supplementation values were statistically significantly different: ${ }^{*} P<0.05,{ }^{* *} P<0.01,{ }^{* * *}$ $P<0.001$ (paired $t$ test).

Table 3. The average contribution of each blood fraction to the ascorbic acid content of the whole blood for normal individuals $(n)$ and those supplemented with ascorbic acid (s)

(Values in parentheses are a percentage of total)

\begin{tabular}{lcccccc}
\hline & Subject & Granulocyte & Mononuclear & Platelet & Erythrocyte & Plasma \\
\hline Cell count $\left(\times 10^{-9}\right.$ cells/1) & $\mathrm{n}$ & 3.68 & 2.40 & 277 & 4750 & - \\
& $\mathrm{s}$ & 3.56 & 2.77 & 265 & 4560 & - \\
Packed cell volume & $\mathrm{n}$ & - & - & - & - & 0.43 \\
& $\mathrm{~s}$ & - & - & - & - & 0.40 \\
Ascorbic acid content & $\mathrm{n}$ & 0.53 & 1.37 & 0.030 & 0.0039 & 45 \\
Blood contribution $(\mu \mathrm{mol} / \mathrm{l})$ & $\mathrm{s}$ & 0.71 & 1.39 & 0.055 & 0.0059 & 118 \\
& $\mathrm{n}$ & $1.95(4)$ & $3.29(6)$ & $8.31(16)$ & $18.5(36)$ & $19.4(38)$ \\
& $\mathrm{s}$ & $2.53(3)$ & $3.85(4)$ & $14.6(15)$ & $26.9(28)$ & $47.2(50)$ \\
\hline
\end{tabular}

* $\mu \mathrm{mol} / 10^{9}$ cells; $\mu \mathrm{mol} / 1$ for plasma.

\section{Ascorbic acid content of various blood fractions}

The ascorbic acid content of the various blood fractions was determined for forty-one healthy individuals. The mean and standard deviation of each of these fractions are shown in Table 2. There was no significant difference between the values for the males and the females and so their results were combined. The results for buffy layer, platelet, erythrocyte and plasma were in good agreement with previous literature values (Barkhan \& Howard, 1958; Denson \& Bowers, 1961; Lloyd et al. 1972). We are not aware of any previously reported values for granulocytes and mononuclear cells.

Mononuclear cell ascorbic acid content corrected for platelet contamination is also shown. The platelet ascorbic acid accounts for approximately $20 \%$ of the apparent mononuclear cell ascorbic acid which is a significant degree of contamination. However, the corrected values correlated well with the uncorrected values $(r 0.93)$.

Values for normal individuals supplemented with ascorbic acid are also given in Table 2. Comparison with the unsupplemented values shows a significant increase in buffy layer, granulocyte, platelet, erythrocyte and plasma values but not in mononuclear cell ascorbic acid content. 
Table 4. Calculated average concentration of ascorbic acid in various fractions of whole blood for normal individuals ( $n$ ) and those supplemented with ascorbic acid (s)

\begin{tabular}{|c|c|c|c|c|c|}
\hline \multirow[b]{3}{*}{ Subject } & \multirow{3}{*}{$\begin{array}{l}\text { Cell volume } \\
\left(\times 10^{15} \mathrm{l}\right)\end{array}$} & \multicolumn{4}{|c|}{ Ascorbic acid } \\
\hline & & \multicolumn{2}{|c|}{$\begin{array}{c}\text { Content } \\
\left(\times 10^{9} \mu \mathrm{mol} / \text { cell }\right)\end{array}$} & \multicolumn{2}{|c|}{$\begin{array}{l}\text { Concentration } \\
(\mu \mathrm{mol} / \mathrm{l})\end{array}$} \\
\hline & & $n$ & s & $n$ & s \\
\hline Granulocyte & $450^{*}$ & 0.53 & $0 \cdot 71$ & 1200 & 1600 \\
\hline Mononuclear & $360 t$ & $1 \cdot 37$ & $1 \cdot 39$ & 3800 & 3900 \\
\hline Platelet & $16 t$ & 0.030 & 0.055 & 1900 & 3400 \\
\hline Erythrocyte & $90 \$$ & 0.0039 & 0.0059 & 43 & 66 \\
\hline Plasma & & & & 45 & 118 \\
\hline
\end{tabular}

* Tivey et al. (1951).

+ Mixed fraction containing large and small lymphocytes and monocytes average cell volume estimated from values of Tivey et al. (1951) and their relative distribution.

† Barkhan \& Howard (1958).

$\S$ Davidsohn \& Nelson (1974).

Contribution of the various fractions to the whole blood ascorbic acid content

The mean whole blood ascorbic acid content can be calculated from the average cell count and the mean ascorbic acid content of each fraction. The results of such calculations (Table 3) give a mean whole blood ascorbic acid content which compares well with the value of $51 \mu \mathrm{mol} / 1$ found by Griffiths et al. (1967). It can be seen that most of the ascorbic acid is in the erythrocytes and plasma while the leucocytes contain a relatively small proportion of the total blood ascorbic acid. These results confirm the findings of Barkhan \& Howard (1958).

\section{Concentration of ascorbic acid in various cell types}

The concentration of ascorbic acid in a particular cell type can be calculated from the ascorbic acid content and the cell volume. Table 4 shows the results of calculations based on the ascorbic acid content of various fractions and published values for cell sizes. These calculations make assumptions regarding uniform distribution of ascorbic acid between similar cell types and within individual cells. In addition, the mononuclear cell fraction consists of a variety of cells of different sizes (monocytes, large and small lymphocytes) and so an average cell size has been estimated from the relative numbers of these cell types.

Despite these limitations certain points can be made. A comparison of the mean cell concentration with the mean plasma concentration indicates that granulocytes, mononuclear cells and platelets all concentrate ascorbic acid over the normal range of plasma concentrations, while erythrocytes do not appear to do so to any great extent.

\section{Relationship between the ascorbic acid content of the various blood fractions and the plasma ascorbic acid content}

The ascorbic acid content of the various blood fractions was compared with the associated plasma ascorbic acid content for the forty-one normal individuals. Plots of these relationships for each fraction are shown in Figs. 1-4. Significant positive correlations were found for granulocyte, platelet and erythrocyte preparations but not for the mononuclear preparation (platelet corrected or uncorrected). The significance of this finding is discussed later. The values for the supplemented individuals are also shown on Figs. 1-4 as the mean and 
Table 5. Statistical values for relationships between granulocyte, mononuclear cell, platelet and erythrocyte ascorbic acid content and the plasma ascorbic acid concentration

\begin{tabular}{|c|c|c|c|c|c|}
\hline & \multirow[b]{3}{*}{ Correlation } & \multicolumn{4}{|c|}{ Linear regression analysis } \\
\hline & & \multicolumn{2}{|c|}{ Gradient } & \multicolumn{2}{|c|}{ Intercept } \\
\hline & & Mean & SD & Mean & SD \\
\hline Granulocyte & $0 \cdot 58^{* * *}$ & 0.0039 & 0.0009 & $0 \cdot 36^{* * *}$ & 0.02 \\
\hline Mononuclear cell (uncorrected) & 0.11 & - & - & - & - \\
\hline Mononuclear cell (corrected) & $0 \cdot 01$ & - & - & - & - \\
\hline Platelet & $0 \cdot 53^{* * *}$ & 0.00035 & 0.00008 & $0.014^{* *}$ & 0.002 \\
\hline Erythrocyte & $0 \cdot 57^{* * *}$ & 0.000037 & $0-000009$ & $0.0022^{* * *}$ & 0.0002 \\
\hline
\end{tabular}

Correlations were statistically significant and intercepts statistically significantly different from zero: ** $P<0.01$.*** $P<0.001$ ( $t$ test).

standard deviation. The reason for this is that the plasma values, unlike the unsupplemented individuals, are dependent on the time between sampling and the oral dose of ascorbic acid and so do not reflect the true average plasma ascorbic acid concentration that the cells are exposed to. Linear regression analysis was carried out on the values for the granulocyte, platelet and erythrocyte preparations. The results (Table 5) show positive intercepts which were shown to be significantly different from zero.

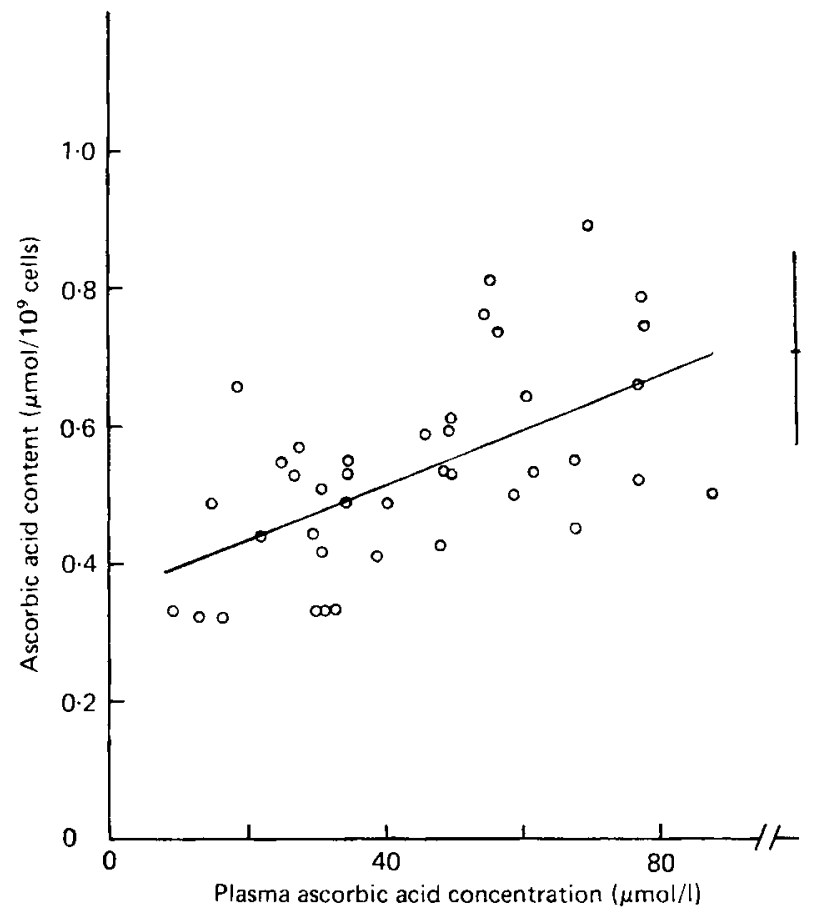

Fig. 1. The relationship between the granulocyte ascorbic acid content $\left(\mu \mathrm{mol} / 10^{\circ}\right.$ cells) and the corresponding plasma concentration $(\mu \mathrm{mol} / 1)$ for forty-one unsupplemented, healthy individuals $(0)$. The mean value and standard deviation of granulocyte ascorbic acid in sixteen of these individuals, post supplementation with ascorbic acid, is represented by vertical bars. 


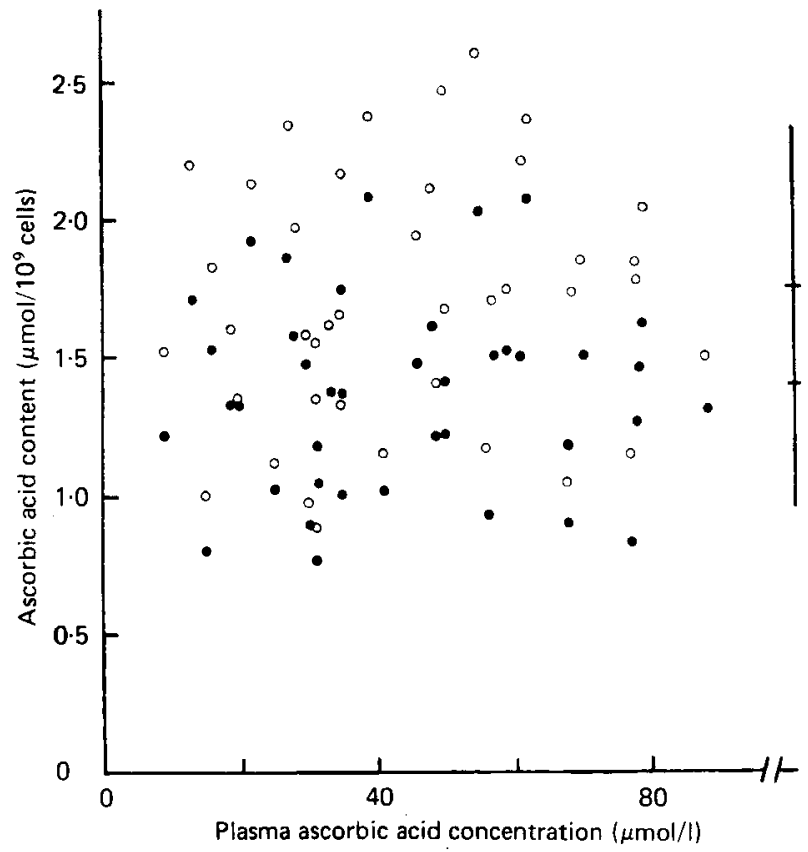

Fig. 2. The relationship between the mononuclear cell ascorbic acid content $\left(\mu \mathrm{mol} / 10^{\circ} \mathrm{cells}\right)$ and the corresponding plasma concentration $(\mu \mathrm{mol} / \mathrm{l})$ for forty-one unsupplemented, healthy individuals before (O) and after (O) correction for platelet contamination. The mean values and standard deviations of mononuclear ascorbic acid in sixteen of these individuals, post supplementation with ascorbic acid, are represented by vertical bars.

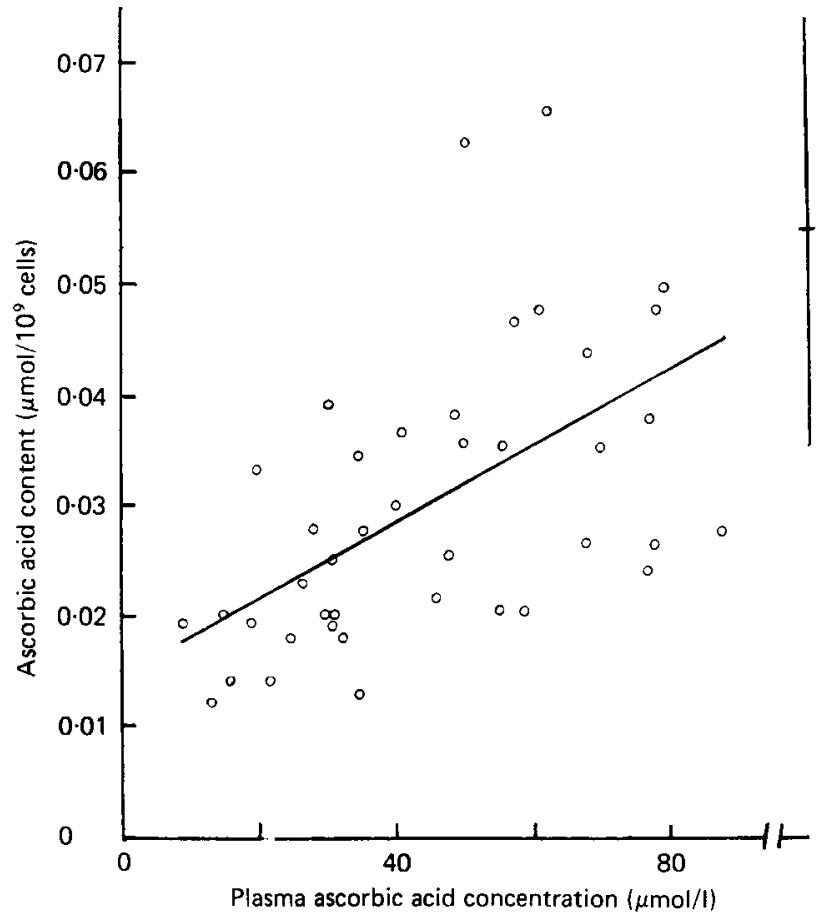

Fig. 3. The relationship between the platelet ascorbic acid content ( $\left.\mu \mathrm{mol} / 10^{9} \mathrm{cells}\right)$ and the corresponding plasma concentration $(\mu \mathrm{mol} / \mathrm{l})$ for forty-one unsupplemented, healthy individuals $(O)$. The mean value and standard deviation of platelet ascorbic acid in sixteen of these individuals, post supplementation with ascorbic acid, is represented by vertical bars. 


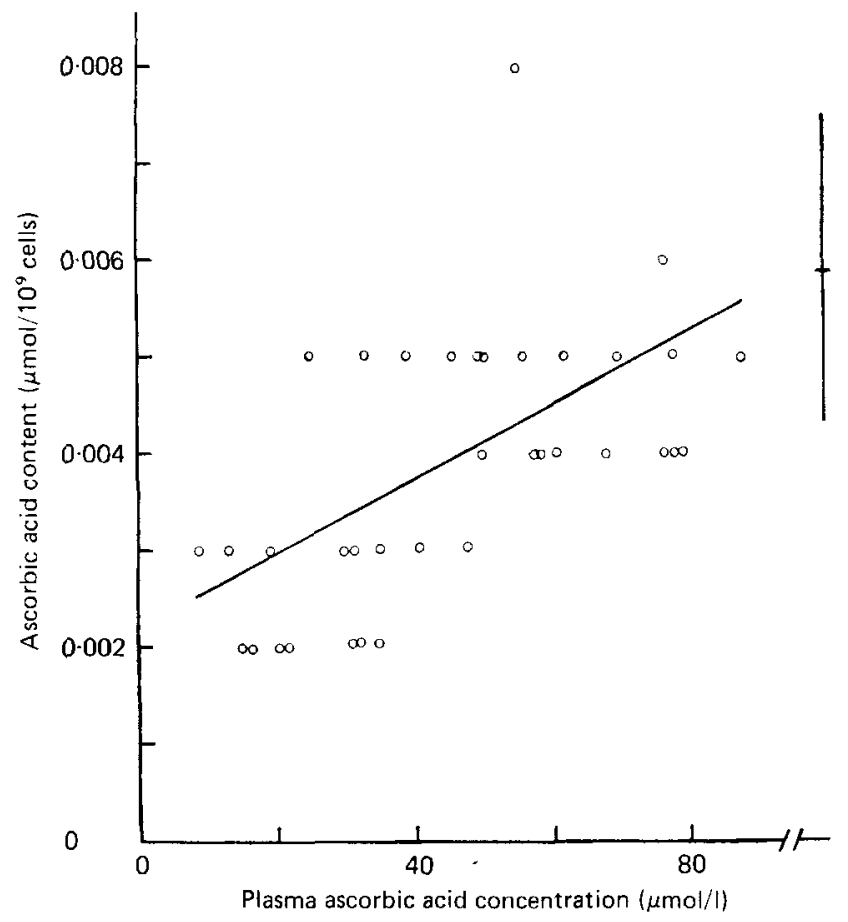

Fig. 4. The relationship between the erythrocyte ascorbic acid content $\left(\mu \mathrm{mol} / 10^{9} \mathrm{cells}\right)$ and the corresponding plasma concentration $(\mu \mathrm{mol} / 1)$ for forty-one unsupplemented, healthy individuals $(O)$. The mean value and standard deviation of erythrocyte ascorbic acid in sixteen of these individuals, post supplementation with ascorbic acid, is represented by vertical bars.

\section{DISCUSSION}

The traditional approach to the assessment of blood-borne ascorbic acid has concentrated on the plasma and leucocyte fractions (Lowry et al. 1946). However, the standard methods of isolating the leucocyte fraction (Denson \& Bowers, 1961; Loh \& Wilson, 1971 b) also isolate the platelets (Gibson et al. 1966). These platelets may in fact be responsible for up to $80 \%$ of the ascorbic acid attributed to the leucocytes with this contribution varying with the ratio, platelets:leucocytes (Evans et al. 1980). We have shown that the value for this ratio can vary widely even in healthy individuals (Evans et al. 1980). In addition, the leucocytes themselves may vary considerably both in the relative proportions of granulocytes and mononuclear cells (mainly lymphocytes) and in their respective ascorbic acid content. It is apparent, therefore, that the leucocyte (buffy layer) estimation is rather crude and subject to considerable difficulty in interpretation.

We have attempted to overcome these difficulties by separating whole blood into various fractions namely granulocytes, mononuclear cells, platelets, erythrocytes and plasma. However, these cellular fractions still had some degree of contamination with cells from other fractions. In each case this would cause an overestimate of the apparent ascorbic acid content of the fraction. In particular, the platelet contamination of the mononuclear cell fraction was sufficient to result in a $20 \%$ overestimate of the mononuclear cell ascorbic acid content. A correction for this could be made from the platelet count and the platelet ascorbic acid content.

In spite of this limitation in methodology, our results show considerable variation in the ascorbic acid content of the various cellular elements of blood. Thus mononuclear 
leucocytes (mainly lymphocytes) have a greater ascorbic acid content than granulocytes, both on a per cell basis and as a calculated intracellular concentration, confirming the findings of Vallance et al. (1978). Platelets contain considerable amounts of ascorbic acid because although on a per cell basis the amount of ascorbic acid is small, their relative size results in the calculated intracellular concentration being between that of the mononuclear leucocytes and the granulocytes. Moreover, their relative abundance in the blood means that quantitatively they contain more ascorbic acid than the leucocytes.

Erythrocytes, because of their abundance, account for $36 \%$ of the blood-borne ascorbic acid although their actual ascorbic acid content is low as has been previously shown (Barkhan \& Howard, 1958). Indeed, their average calculated intracellular concentration is the same as the mean plasma concentration in normal individuals, which suggests that they do not concentrate ascorbic acid to any appreciable extent. However, the relationship between the erythrocyte ascorbic acid content and the plasma concentration (Fig. 4) suggests that there may be some retention of ascorbic acid at low plasma concentrations because the results indicate that there is a positive intercept.

In contrast to the erythrocytes, the other cell types in the blood all show marked ability to concentrate ascorbic acid against a concentration gradient. For example, with mononuclear leucocytes there is an over 80-fold increase in concentration compared with the plasma. It would be expected that the maintenance of such a concentration gradient would involve the expenditure of metabolic energy.

Consideration of Figs. 1-3 show that, unlike the mononuclear cells, the granulocytes and platelets show a definite dependence on the ascorbic acid content of the plasma, and that supplementation of these individuals with ascorbic acid will increase the ascorbic acid content of these cells. The mononuclear cells appear to maintain their high ascorbic acid content despite variations in the plasma ascorbic acid concentration and ascorbic acid supplementation. All these cell types appear to maintain a high content of ascorbic acid at low plasma concentrations as extrapolation to zero plasma concentration shows. This is in line with previous results obtained with leucocyte (buffy layer) ascorbic acid measurements (Griffiths et al. 1967; Loh \& Wilson, 1971 a). However, the individuals used in this study were all healthy and on free diets, so that comparatively few of them had low plasma ascorbic acid levels and none of them were on ascorbic acid-free diets. This makes the interpretation of the extrapolation to zero plasma content uncertain.

The view expressed by some authors (Lewin, 1976; MacLennan \& Hamilton, 1976) that leucocytes carry ascorbic acid to the tissues, e.g. seats of inflammation, infarction, healing and neoplasia, requires re-appraisal. It seems to us that since the leucocytes carry such a small proportion of the blood-borne ascorbic acid $(10 \%)$ it is likely that the plasma itself must be of prime importance in carrying ascorbic acid to the tissues, particularly as it seems unlikely that the blood cells are exclusively endowed with the ability to concentrate ascorbic acid from the plasma.

The fact that platelets, granulocytes and mononuclear cells concentrate ascorbic acid suggests that this substance has an important role to play in these cell's physiological function. Thus the phagocytic action of granulocytes (Leibovitz \& Siegel, 1978), blastogenesis (Yonemoto et al. 1976) and immunoglobin production (Prinz et al. 1977; Vallance, 1977) in lymphocytes, and platelet adhesiveness (Wilson et al. 1967; Sahud \& Aggeler, 1970) may all be influenced by their ascorbic acid content. Manku et al. (1979), discussing the metabolic pathway involved in prostaglandin El (PGE1) production, note the key role of ascorbic acid in the final step, i.e., the conversion of dihomogammalinolenic acid to PGE1. It is suggested that PGEl has an important role in the regulation of lymphocyte action (Horrobin, Manku et al. 1979) and also that platelet adhesiveness may depend upon the PGE1 content (Horrobin, Oka et al. 1979). 
Thus future work is now required to define the role of ascorbic acid in intracellular metabolism. In particular, the efficiency with which mononuclear cells concentrate ascorbic acid and the involvement of the mononuclear cell in immunocompetence merits detailed study in view of the reported efficacy of mega-ascorbic acid therapy in the management of viral (Murata, 1975) and neoplastic disorders (Cameron \& Campbell, 1974; Campbell \& Jack, 1979; Campbell, 1980).

The authors thank the laboratory staff at Hairmyres Hospital for their assistance during this study. They are grateful for research grants (for L.C.) from the Endowment Fund of Lanarkshire Area Health Board, the Linus Pauling Institute of Science and Medicine, USA and the National Foundation for Cancer Research (USA).

\section{REFERENCES}

Barkhan, P. \& Howard, A. N. (1958). Biochem J. 70, 163.

Barton, G. M. G. \& Roath, O. S. (1976). Int. J. Vitam. Nutr. Res. 46, 271.

Boyum, A. (1968). Scand. J. Clin. Lab. Invest. 21, Suppl. 77.

Cameron, E. \& Campbell, A. (1974). Chem. Biol. Interact. 9, 285.

Campbell, A. (1980). Chem. Biol. Interact. 30, 305.

Campbell, A. \& Jack, T. (1979). Scott. Med. J. 24, 151.

Davidsohn, I. \& Nelson, D. A. (1974). In Clinical Diagnosis by Laboratory Methods, p. 123 [I. Davidsohn and J. B. Henry, editors]. London: W. B. Saunders.

Denson, K. W. \& Bowers, E. F. (1961). Clin. Sci. 21, 157.

Evans, R. M., Currie, L. \& Campbell, A. (1980). Ann. Clin. Biochem. 17, 252.

Gibson, S. L. M., Moore, F. M. L. \& Goldberg, A. (1966). Br. Med. J. i, 1152.

Griffiths, L. L., Brocklehurst, J. C., Scott, D. L., Marks, J. \& Blackley, J. (1967). Geront. Clin. 9, 1.

Horrobin, D. F., Manku, M. S., Oka, M., Morgan, R. O., Cunnane, S. C., Ally, A. I., Ghayur, T., Schweitzer, M. \& Karmali, R. A. (1979). Med. Hypotheses 5, 969.

Horrobin, D. F., Oka, M. \& Manku, M.S. (1979). Med. Hypotheses 5, 849.

Hume, R. \& Weyers, E. (1973). Scott. Med. J. 18, 3.

Leibovitz, B. \& Siegel, B. V. (1978). Int. J. Vitam. Nutr. Res. 48, 159.

Lewin, S. (1976). Vitamin C: Its Molecular Biology and Medical Potential. London: Academic Press.

Lloyd, J. V., Davis, P. S., Emery, H. \& Lander, H. (1972). J. Clin. Path. 25, 478.

Loh, H. S. \& Wilson, C. W. M. (1971a). Br. Med. J. iii, 733.

Loh, H. S. \& Wilson, C. W. M. (1971 b). Int. J. Vitam. Nutr. Res. 41, 90.

Lowry, O. H., Bessey, O. A., Brock, M. J. \& Lopez, J. A. (1946). J. biol. Chem. 166, 111.

MacLennan, W. J. \& Hamilton, J. C. (1976). Age Ageing 5, 43.

Manku, M. S., Oka, M. \& Horrobin, D. F. (1979). Prostaglandins Med. 3, 129.

Murata, A. (1975). Proc. 1st int. Cong. Microbiol. Soc. Sci. Counc. Jap. 3, 432.

Prinz, W., Bortz, R., Bregin, B. \& Hersch, M. (1977). Int. J. Vitam. Nutr. Res. 47, 248.

Sahud, M. A. \& Aggeler, P. M. (1970). Proc. Soc. exp. Biol. 134, 13.

Tivey, H., Li, J. G. \& Osgood, E. E. (1951). Blood 6, 1013.

Vallance, B. D., Hume, R. \& Weyers, E. (1978). Br. Heart J. 40, 64.

Vallance, S. (1977). Br. med. J. ii, 437.

Wilson, P. A., McNicol, G. P. \& Douglas, A. S. (1967). Lancet i, 975.

Yonemoto, R. H., Chretien, P. B. \& Fehniger, T. F. (1976). Proc. Am. Ass. Cancer Res, 17, 288. 